Submitted $12^{\text {th }}$ April 2021

Accepted 15 $5^{\text {th }}$ June 2021

\title{
ANALYSIS OF TIRTA EMPUL DEVELOPMENT STRATEGY AS WELLNESS TOURIST ATTRACTION IN NEW NORMAL ERA
}

\author{
Ni Ketut Wiwiek Agustina ${ }^{1}$, Putu Gde Arie Yudhistira ${ }^{2}$ \\ Politeknik Pariwisata Bali, Indonesia ${ }^{1,2}$ \\ agustina.wiwiek@ppb.ac.id ${ }^{1}$ \\ arie.yudhistira@ppb.ac.id ${ }^{2}$
}

\begin{abstract}
The Covid-19 pandemic is a very dangerous epidemic that affects the order of human lives around the world. The existence of the Covid-19 pandemic has made everyone without exception have to be able to adapt to the new life order or new normal era in accordance with health protocols. In this new normal era, many people have begun to take short, cost-effective trips and tend to seek pleasure and health simultaneously to reduce boredom and stress when forced to stay at home during lockdowns. One of the tourism trends that is coming back is Wellness Tourism. The current trend of Wellness Tourism is one of the options for restoring the passion of tourism in Bali Province which will encourage public interest in travelling. Tirta Empul is one of the tourist attractions that have the potential to support wellness tourism as a Wellness Tourist Attraction. This research was conducted in Tirta Empul which aims to analyze development strategies related to the wellness tourist attraction. This study uses data processing analysis carried out by SWOT through an analysis process of internal factors (IFAS) and external factors (EFAS). The results showed that the Grand Strategy obtained in this study is the $S$ (Strength) - O (Opportunity) Strategy, so that there are opportunities to develop Tirta Empul as a Wellness Tourist Attraction in a New Normal Era.
\end{abstract}

Keywords: Covid-19, Wellness Tourism, SWOT analysis, New Normal Era

\section{INTRODUCTION}

By the end of December 2019, the world was faced with a virus outbreak known as Covid-19. The World Health Organization (WHO) also officially designated Covid-19 as a pandemic. This results in the limitation of all activities carried out by humans because they have to follow the Ministry of Health Circular Number HK.02.01/MENKES/335/2020 concerning the Covid-19 Prevention Health Protocols, such as wearing masks, keeping a distance, wash hands, work, learn and pray from home. In early 2020, President Joko Widodo through the Head of the National Disaster Management Agency, Doni Monardo, declared the Covid19 outbreak as a World National disaster, where Indonesia is currently in a state of emergency response for the non-natural disaster of the Covid-19 pandemic (Rokom, 2021). 
The condition of the Covid-19 Pandemic emergency in Indonesia has given significant changes to the current lifestyle of the people. In today's new normal era, people are looking for both pleasure and health at the same time. This happens because of limited activities that make everyone stay at home and feel boredom as a result of the Covid-19 pandemic. Health or Wellness Lifestyle is a new Lifestyle Trend in today's new life order. The development of the potential for Wellness tourism in Indonesia is currently being carried out with the aim of maintaining the physical and mental fitness of tourists in a new normal era. Baparekraf Director of Inter-institutional Relations, K. Candra Negara explained

"Wellness Tourism has actually been developed in Indonesia in 2012 and he assesses that this new life order is the right moment to re-develop the potency of Wellness Tourism in Indonesia." (Ministry of Tourism and Creative Economy, 2020)

According to the Global Wellness Institute, Wellness Tourism is a tour that is related to efforts to maintain and improve the inner and physical well-being of a person. " (Global Wellness Institue, 2021). So that the concept of wellness is very suitable to be one of the strategies to re-promote the tourism industry in Indonesia. Wellness Tourism itself consists of several components, namely SPA (Sanitas Per Aqua), Hot / Mineral Springs, Fitness / Fitness, Retreats / Rituals and trips to nature. The initial form of Wellness Tourism is to visit mineral springs or hot springs that have occurred during the Neolithic and Bronze ages in Europe (Ross, 2001).

Along with the development of Wellness Tourism in the world, Indonesia as one of the world's tourist destinations has also developed a Wellness Tourism destination. One of the destinations in Indonesia that is quite popular is the area of Ubud, Bali. Ubud is one of the SPA destinations on the island of Bali which is very popular with its Health and Wellness. Bali was awarded the best Spa and Fitness Tourism Destination award from the Selling Travel Magazine (Nusa Bali, 2017). In addition, in 2009 Bali also received the "World's Best Spa Destination" award given by Berlin-Senses Magazine which was received at the International Tourism Bourse (ITB) in Berlin, Germany (Sutrisna, 2009). This is a worldwide recognition of Indonesia's success in providing the Best Spa and Wellness destinations.

Judging from the popularity of SPA as Wellness Tourism in Bali, tourism attractions based on Health and Wellness in the form of mineral / hot springs or self-cleansing on the island of Bali are still very rarely found. This phenomenon is quite interesting because the island of Bali has a lot of natural and cultural potencies such as Sebatu Waterfall Tegallalang Gianyar, and Tirta Sudamala Temple Blahbatuh Bangli Rahyuda (2014) that can be managed as other Health and Wellness tourist attractions, one of these potencies is Tirta Empul Holy Spring Temple. Tirta Empul Temple is one of the temples which is a means of selfcleansing for the famous 'Melukat' on the island of Bali.

According to Rahyuda (2014), Tirta Empul is included in a spring that has a potential Wellness Tourism destination in the form of 'Melukat' Self-Cleansing on the island of Bali. Tirta Empul is one of the Khayangan Jagad temples as well as a holy place to perform 'melukat' rituals located in Manukaya Village, Tampaksiring, Gianyar, where in the Central Jaba section there is a sacred place in the form of a 
pond that has a spring in the middle and spouts water from the ground. Tirta is holy water and Empul is water that gushes from the ground. This spring is then flowed into the lower pool in the south through 26 fountains. It is in this southern shower that many people clean themselves or do melukat.

In Kakawin Usana Bali, Tirta Empul Temple is a place to treat the Gods troops after fighting Mayadanawa troops. The holy water of Tirta Empul Temple has extraordinary properties to heal disease and can revive the troops of the Gods who have died. The efficacy of this holy water seems to be a supporting factor for the community to do melukat at Tirta Empul Temple in the hope that it can cure various diseases (Ministry of Education and Culture, 2019).

Tirta Empul has now also become a tourist attraction that is in great demand by tourists, so it cannot be denied that Tirta Empul Temple has become one of the famous tourist attractions in Bali. Ministry of Tourism and Creative Economy (2020) stated that Tirta Empul is ready to be reopened by accomplishing the Health Protocol requirements that have been established and used as a pilot project for tourists attractions in a new normal era so that the implementation of the Health Protocol is an obligation that must be considered and implemented by all tourist attractions in order to operate and receive tourists visits. The implementation of this health protocol also requires the development of an appropriate strategy for tourist attractions during the current Covid-19 pandemic. In addition, Tirta Empul temple has the potential as a wellness tourist attraction in Bali where currently the wellness tourism trend is reviving so that the managers of Tirta Empul must be able to do several ways and strategies regarding the development of Tirta Empul as a Wellness Tourist Attraction in a New Normal using Health Protocol rules. Further research is needed on the Analysis of Tirta Empul Development Strategy as a Wellness Tourist Attraction in New Normal Era. Meikassandra, Prabawa, dan Mertha (2020) stated that Gianyar Regency, especially the Ubud area, is still in the development stage but the demand for Wellness Tourism is still quite high because it is still competitive among services, providers, and forms of activities. Previous research on Tirta Empul as a Wellness Tourist Attraction has not been found. Therefore, this research is made by descriptive qualitative method on the locus.

\section{METHODOLOGY}

This research of "Analysis of Tirta Empul Development Strategy as a Wellness Tourist Attraction in New Normal Era" is designed using descriptive qualitative research method. Qualitative research is a research method based on the principles of postpositivism or interpretive research to examine the condition of an object, where the researcher is a key instrument whose data collection technique is carried out by combining 3 techniques, namely observation, interviews, and documentation and the data obtained leads to qualitative data analyzed Inductively / Qualitatively, and the results are potential findings and problems, the uniqueness of the object, the meaning of an event, protests and social interactions, the certainty of data correctness, the construction of phenomena and the findings of hypotheses (Sugiyono, 2020).

This research was conducted at Tirta Empul Tourist Attractions, Gianyar Regency, Bali. This study uses primary data and secondary data. Sugiyono (2015) explained that Primary Data is data obtained directly, where primary data is 
obtained by interviewing the manager of the Tirta Empul tourist attraction, stakeholders, village heads and tourists. Apart from primary data, there is secondary data which is very necessary to improve the quality of studies in this study. Secondary data is obtained from reports published by the government, books, government websites, related journals, and other relevant sources and is not directly obtained.

The data collection technique was carried out by conducting a field survey. Researchers make preparations and initial data collection through:

\section{Observation}

According to Sugiyono (2015) observation is an activity loading research on an object. When viewed on the process implementation of data collection, observation can be divided into participants and non-participant. This study uses participant observation where the observations made are part observation by the observer by taking part in the lives of the people who will be observed. Observations were carried out in the Tirta Empul Temple Area by observing whether the health protocol had been carried out by the Tirta Empul officers properly or not.

2. Interview

The interview is a data collection technique that is carried out by conducting direct questions and answers to the informants under study. According to Arikunto (2013) Interviews were conducted by asking a number of questions freely and still within the interview guidelines that had been made. In-depth interviews (Depth Interview) will be carried out to several trusted resource persons in the development of Tirta Empul as Wellness Tourist Attraction. Interviews were conducted by the manager of Tirta Empul Temple, represented by the Field Coordinator of Tirta Empul Temple to get information about the situation during the Covid-19 pandemic.

\section{Document Study}

Sugiyono (2015) Defining documentation is a method for obtaining data and information in the form of books, archives, numbers and pictures, reports and information to support the research undertaken. Information obtained through the book Ritual Bathing written by Rahyuda (2014) describes Tirta Empul Temple as one of the potential attractions of melukat in Bali. In addition, the journal written by Meikassandra et al. (2020) provides an overview of Wellness Tourism in Bali. 


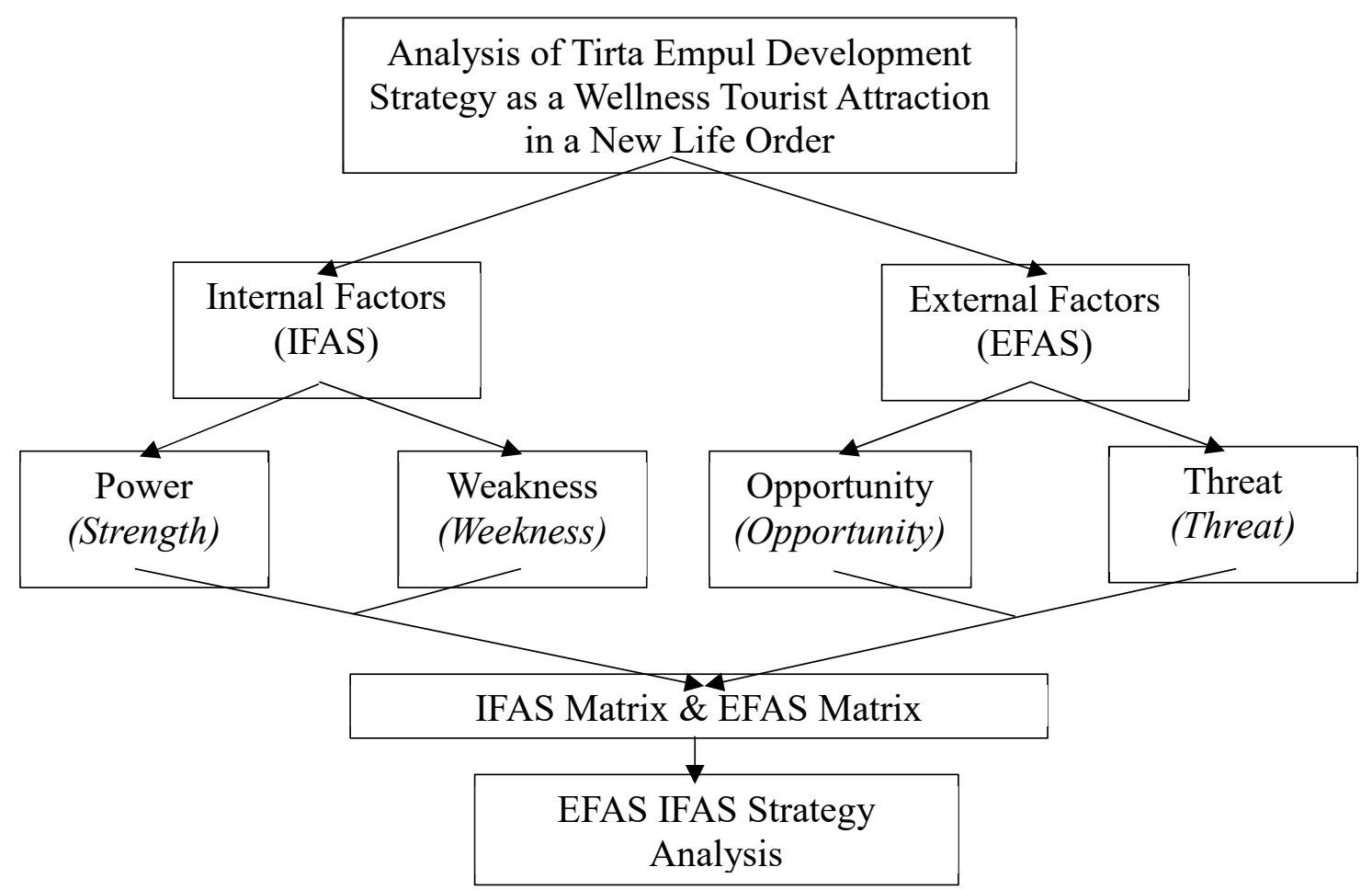

Source: Research Modification (Soeprato \& Hindarwati, 2013)

All data that have been obtained and collected then analyzed by maximizing strengths and opportunities and minimizing weaknesses and threats (Rangkuti, 2006). This SWOT analysis if applied accurately, will provide detailed descriptive information about the conditions of the Tirta Empul tourist attraction which is used as a basic reference to design a development strategy.

\section{RESULTS AND DISCUSSION}

1. Overview of Tourism Attractions in Tirta Empul, Tampaksiring, Gianyar in a New Normal Era

Tirta Empul Temple is one of the Sad Kahyangan or Khayangan Jagat temples in Bali, which is located in Manukaya Village, Tampaksiring District, Gianyar Regency. Astronomically the location of Tirta Empul Temple is at 115018 '43 "East Longitude and 80 10" 30 "South Latitude, 479 meters above sea level, where the temperature of Tirta Empul Temple is $230 \mathrm{o}$ Celsius with annual rainfall reaching $1618 \mathrm{~mm}$, and $76 \%$ humidity. The air at Tirta Empul Temple is very humid compared to the surrounding hills because the location of Tirta Empul Temple is perhaps the lowest. Currently, the condition of Tirta Empul Temple is well maintained because it is a tourist attraction that is directly managed and monitored by the government and local traditional villages. tourist attraction visited by many tourists, This area is recorded as being in accordance with the concept of protection / preservation which is stipulated in the Cultural Heritage Law. In addition, efforts have been made to differentiate between the non-sacred (profane) and sacred areas. Profane areas are opened for public interest, such as toilets, art shops, parking lots and tickets. 
As for the sacred area, which is an area of activity related to religious ritual activities, this temple is famous for its holy spring which is used for the "Melukat" ritual for Hindus in Bali. This resulted in many tourist visits to Tirta Empul Temple. The existence of the Covid-19 pandemic in early 2020 in Indonesia resulted in the temporary closure of Tirta Empul's Tourism Attraction in light of the increasing number of Covid-19 cases and around July 2020 Tirta Empul was reopened with very strict health protocol regulations in accordance with the regulations. The existence of the Covid-19 Pandemic outbreak greatly impacted the number of tourist visits to Tirta Empul which made visits decrease drastically from domestic to foreign tourists.

2. The Potency of Tirta Empul Holy Spring Temple as a Wellness Tourist Attraction in New Normal Era

Tirta Empul Temple or Tirta Empul Holy Spring Temple has a dazzling beauty. The uniqueness of Tirta Empul Temple is that it has a melukat area which is in great demand by domestic and foreign tourists. In terms of the arrangement of the yard and trees, it looks very neat and clean so that it makes the atmosphere around Tirta Empul feel comfortable. In addition, next to Tirta Empul Temple there is the Presidential Palace of the Republic of Indonesia where the Palace is built on hilly land overgrown with green grass. This adds to the beauty of Tirta Empul.

Based on the results of interviews with key informants of the Tirta Empul tourist attraction by Mr. I Wayan Suweta as the field coordinator representing Tirta Empul managers who at that time was unable to attend to explain:

"The potency of Tirta Empul from other tourist objects is that Tirta Empul has a spiritually cleansing place or melukat which is in demand by many tourists and then has a very large yard with a clean and beautiful arrangement. Tirta Empul has also implemented a very good Health Protocol according to the existing CHSE, such as, there is a hand washing area near the entrance, check the temperature, and tourists must wear a mask. After that, new tourists can buy tickets at the counter then tickets at the scanner. Then at the door before entering the core zone of the Tirta Empul temple there is an officer who will give you a scarf or sarong to enter the temple. Kemenparekraf is very helpful in promoting DTW in Gianyar during the Covid-19 pandemic, especially Tirta Empul, such as educational assistance, providing an understanding of the CHSE Protocol and promotion through social media accounts".

The beauty of Tirta Empul Temple is also inseparable from the arrangements of Tirta Empul Temple Managers. Tirta Empul managers is working with the Gianyar Regency Tourism Office, BPD (Village Consultative Body), and Traditional Bendesa to manage the Tirta Empul Tourism Destination. In 2020, the Ministry of Tourism and Creative Economy is also working with Tirta Empul managers to revive Tirta Empul tourist visits during this Pandemic with results such as Sapta Pesona and existing Health Protocol Facilities. 

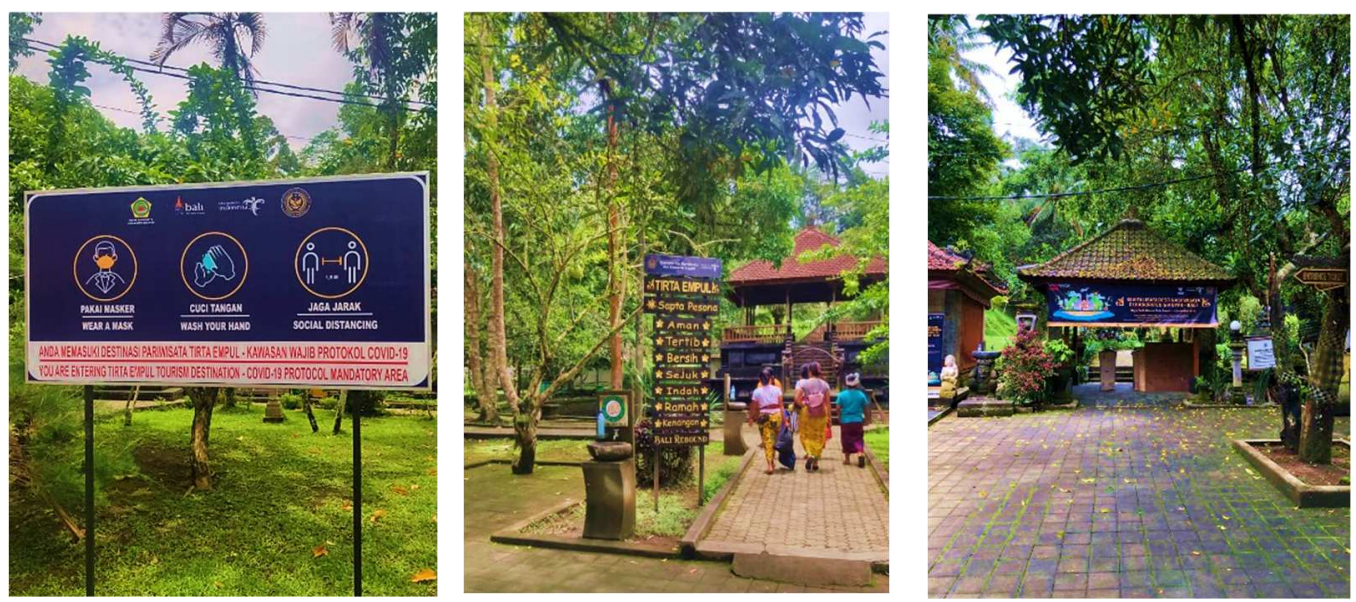

Figure 1. Ministry of Tourism and Creative Economy assistance to Tirta Empul Temple related to the reopening of Tirta Empul Temple in accordance with the Health Protocol.

Source: Personal Documentation

\section{SWOT analysis}

By using SWOT analysis, it is expected to get the best strategy for the development of Tirta Empul as a wellness tourist attraction. Maximizing the use of strengths and opportunities and at the same time reducing weaknesses and threats. The SWOT analysis will explain the internal and external factors as follows:

a. External Factor Analysis Strategy (EFAS)

External Factor Analysis Strategy (EFAS) is a factor of tourist attraction which consists of opportunities and threats in attracting tourists to Tirta Empul Tourist Attraction. External analysis was carried out to determine the tourism attractiveness of Tirta Empul in its external environment. As for the external factors in the tourist attraction of Tirta Empul are:

1) Opportunities in developing Tirta Empul as a Wellness Tourist Attraction are:

(a) Wellness tourism is a trend during the Covid-19 pandemic

(b) Tirta Empul's tourist attraction has been reopened to a new life

(c) The high interest of tourists to do the melukat procession

(d) There is government support related to the development of wellness tourism

2) Threats in the development of Tirta Empul as a Wellness Touris Attraction are:
(a) Commercial tourism attraction of Tirta Empul
(b) The sanctity / sacredness of the temple
(c) Virus transmission
(d) Natural disasters
(e) Environmental damage

b. Internal Factor Analysis Strategy (IFAS) 
Internal Factor Analysis Strategy is a factor that comes from the management system of the Tirta Empul Tourist Attraction which is a strength (Strength) and weakness (Weakness). These factors include:

1) Strength, being the strength in the development of the Tirta Empul Tourist Attraction is

(a) Strategic location

(b) A large courtyard with a beautiful and orderly arrangement.

(c) Well done health protocol implementation

(d) There is cooperation related to the management of Tirta Empul between the local government and local traditional villages.

(e) Adequate access

(f) The beauty of Tirta Empul's appeal

(g) Territorial security

2) Weaknesses, which are a weakness in the development of Tirta Empul's tourist attractions, include:

(a) Lack of socialization and education related to Wellness Tourism

(b) Promotion that is still lacking as a Wellness Tourist Attraction

(c) There is no official social media account

(d) Information regarding Tirta Empul is still lacking on the official website of Tirta Empul which is managed by the Gianyar Disparda

4. Tirta Empul Development Strategy as a Wellness Tourist Attraction in New Normal Era

The development of Tirta Empul as a Wellness Tourist Attraction requires the development of several strategies. These strategies must be included in the SWOT analysis matrix where this matrix is used as a clear and detailed description of the opportunities and threats that will be faced, adjusted to their strengths and weaknesses. The following is the SWOT analysis matrix that was carried out :

\begin{tabular}{|c|c|c|}
\hline Factor Identification & Strength (Strength) & Weakness \\
\hline $\begin{array}{l}\text { E } \\
\text { F } \\
\text { A } \\
\text { S }\end{array}$ & $\begin{array}{l}\text { 1) Strategic location } \\
\text { 2) A large courtyard with a } \\
\text { beautiful and orderly } \\
\text { arrangement } \\
\text { 3) Well done health } \\
\text { protocol implementation } \\
\text { 4) There is cooperation } \\
\text { related to the } \\
\text { management of Tirta } \\
\text { Empul between the local }\end{array}$ & $\begin{array}{l}\text { 1) Lack of socialization } \\
\text { and education related to } \\
\text { Wellness Tourism } \\
\text { 2) Promotion that is still } \\
\text { lacking as a Wellness } \\
\text { Tourist Attraction } \\
\text { 3) No official social media } \\
\text { accounts } \\
\text { 4) Information related to } \\
\text { Tirta Empul that is still } \\
\text { lacking on the official }\end{array}$ \\
\hline
\end{tabular}




\begin{tabular}{|c|c|c|}
\hline & $\begin{array}{l}\text { government and local } \\
\text { traditional villages } \\
\text { 5) Adequate access } \\
\text { 6) The beauty of Tirta } \\
\text { Empul's appeal } \\
\text { 7) Territorial security }\end{array}$ & $\begin{array}{l}\text { website of Tirta Empul } \\
\text { which is managed by } \\
\text { the Gianyar Disparda }\end{array}$ \\
\hline Opportunity & SO strategy & WO strategy \\
\hline $\begin{array}{l}\text { 1) The high interest of } \\
\text { tourists to do the } \\
\text { melukat procession } \\
\text { 1) Wellness Tourism } \\
\text { became a trend } \\
\text { during the Covid-19 } \\
\text { pandemic } \\
\text { 2) The tourism } \\
\text { attraction of Tirta } \\
\text { Empul has been } \\
\text { reopened in a new } \\
\text { life order } \\
\text { 3) There is support } \\
\text { related to the } \\
\text { development of } \\
\text { Wellness Tourism }\end{array}$ & $\begin{array}{l}\text { 1) The strategic location, } \\
\text { adequate access as well } \\
\text { as a large courtyard and } \\
\text { a beautiful arrangement } \\
\text { make Tirta Empul } \\
\text { visited by many tourists } \\
\text { so that the interest of } \\
\text { tourists is very high for } \\
\text { "Melukat" Spiritual self } \\
\text { cleansing in Tirta Empul. } \\
\text { 2) The implementation of } \\
\text { good Health Protocols } \\
\text { supported by the } \\
\text { Wellness Tourism trend } \\
\text { has made Tirta Empul } \\
\text { revive and reopen to a } \\
\text { new life order today } \\
\text { 3) Good cooperation } \\
\text { between Tirta Empul } \\
\text { managers, namely the } \\
\text { Local Traditional Village } \\
\text { and the Regional } \\
\text { Government, supports } \\
\text { the development of } \\
\text { Wellness Tourism. }\end{array}$ & $\begin{array}{l}\text { 1) The existence of a } \\
\text { Wellness Tourism } \\
\text { trend must be } \\
\text { supported by } \\
\text { knowledge or } \\
\text { education related to } \\
\text { Wellness Tourism so } \\
\text { that managers can } \\
\text { properly manage Tirta } \\
\text { Empul as a Wellness } \\
\text { Tourist Attraction } \\
\text { 2) The reopening of Tirta } \\
\text { Empul also requires a } \\
\text { strong promotion such } \\
\text { as promotion through } \\
\text { social media and also } \\
\text { the official website of } \\
\text { Tirta Empul }\end{array}$ \\
\hline Threats & ST strategy & WT strategy \\
\hline $\begin{array}{l}\text { 1) Commercial Tourism } \\
\text { of Tirta Empul } \\
\text { 2) The santity / } \\
\text { sacredness of temple } \\
\text { 3) Virus transmission } \\
\text { 4) Natural disasters }\end{array}$ & $\begin{array}{l}\text { 1) The beauty of Tirta } \\
\text { Empul must also be } \\
\text { maintained by the } \\
\text { sanctity and sacredness } \\
\text { of the temple and also } \\
\text { the normalization must } \\
\text { be considered to the }\end{array}$ & $\begin{array}{l}\text { 1) A balance is needed } \\
\text { between the Promotion } \\
\text { and Commercialization } \\
\text { of the Tirta Empul } \\
\text { Tourist Attraction itself } \\
\text { 2) It is necessary to know } \\
\text { the purpose of Wellness }\end{array}$ \\
\hline
\end{tabular}




\begin{tabular}{|l|l|l|}
\hline $\begin{array}{l}\text { 5) Environmental } \\
\text { damage }\end{array}$ & $\begin{array}{l}\text { administrators of Tirta } \\
\text { Empul Temple } \\
\text { 2) } \begin{array}{l}\text { The implementation of } \\
\text { good Health Protocols } \\
\text { must also be paid } \\
\text { attention to considering } \\
\text { the very fast } \\
\text { transmission of the } \\
\text { Covid-19 virus }\end{array}\end{array}$ & $\begin{array}{l}\text { Tourism during the } \\
\text { Covid-19 period so that } \\
\text { there is no transmission } \\
\text { of the virus }\end{array}$ \\
& $\begin{array}{l}\text { 3) A large yard and a } \\
\text { beautiful arrangement } \\
\text { are the most important } \\
\text { things in order not to } \\
\text { experience } \\
\text { environmental damage } \\
\text { due to tourists who come }\end{array}$ \\
\hline
\end{tabular}

Source: Research Results March 2021

5. SWOT Analysis of Tirta Empul Development Strategy as a Wellness Tourist Attraction in New Normal Era

a. The Strength-Opportunity (SO) Strategy in the Analysis of the Development Strategy of Tirta Empul as a Wellness Tourist Attraction in New Normal Era

Based on the results of the SO table tabulation, the strategy for developing Tirta Empul as a Wellness Tourist Attraction should be, (1) The strategic location, adequate access and a large courtyard and a beautiful arrangement make Tirta Empul visited by many tourists so that the interest of tourists is very high for doing a tour. at Tirta Empul. (2) The implementation of good Health Protocols supported by the Wellness Tourism trend has made Tirta Empul revive and reopen to its current new life order. (3) Good cooperation between Tirta Empul managers, namely the Local Traditional Village and the Regional Government, supports the development of Wellness Tourism.

b. Strength-Threat (ST) Strategy in the Analysis of Tirta Empul Development Strategies as a Wellness Tourist Attraction in New Normal Era

The results of the ST table tabulation, then the strategy for developing Tirta Empul as a Wellness Tourist Attraction is, (1) The beauty of Tirta Empul must be maintained by the purity and sanctity of the temple and also the normalization must be considered by the administrators of Tirta Empul Temple. (2) The implementation of good Health Protocols must be paid attention to considering the very fast transmission of the Covid-19 virus. (3) A large yard and a beautiful 
arrangement are the most important things to prevent environmental damage from visiting tourists.

c. The Weakness-Opportunity (WO) Strategy in Analysis of Tirta Empul Development Strategy as a Wellness Tourist Attraction in New Normal Era

The WO strategy is based on the results of the tabulation of the table above, namely (1) The existence of a Wellness Tourism trend must be supported by knowledge or education related to Wellness Tourism so that managers can manage Tirta Empul as a Wellness Tourist Attraction properly. (2) The reopening of Tirta Empul also requires strong promotions such as promotion through social media and also the official website of Tirta Empul.

d. Weakness Threat (WT) Strategy in the Analysis of Tirta Empul Development Strategies as a Wellness Tourist Attraction in New Normal Era

Based on the results of the tabulation of the WT table, the development strategies that can be done to minimize WT are (1) A balance is needed between Promotion and Commercialization of the Tirta Empul Tourist Attraction itself. (2) It is necessary to know the purpose of Wellness Tourism during the Covid-19 period so that there is no transmission of the virus.

\section{CONCLUSION}

The results of the analysis shows that the development of Tirta Empul as a Wellness Tourist Attraction is in a strong position and has the opportunity. The strategic recommendations given are progressive, meaning that the tourism attraction of Tirta Empul is in prime and steady condition so that it is very possible to continue development and growth to achieve maximum progress. Tourism Attraction Tirta Empul has Strength, namely Tirta Empul has a beautiful attractive attraction with adequate access which is supported by a strategic location, a large yard and a beautifully organized arrangement. The implementation of the health protocol by Tirta Empul is also very good. Externally, Tirta Empul has the opportunity regarding the high interest of tourists to carry out the procession of melukat at Tirta Empul, then Wellness Tourism became a trend during the Covid19 pandemic, reopening the Tourism Attraction of Tirta Empul in a new life order and support related to development.

Based on the SWOT analysis in this study, it was found that strategies to minimize any weaknesses are; i) Conducting online promotions based on Digital Marketing to Tirta Empul Temple and create official social media accounts from Tirta Empul Temple such as Instagram, Facebook and Website, ii) Educating all administrators of Tirta Empul Temple related to Wellness Tourism, iii) Maintaining the environment and sacredness of Tirta Empul Temple. The existence of this strategy is supported the Ministry of Tourism and Creative Economy by making Tirta Empul Temple a tourist attraction in accordance with Health Protocols (Cleanliness, Health, Safety, and Environment Sustainability) such as making a sink to wash hands and hand sanitizer before entering the temple area, there is an automatic temperature checker, restrictions on sacred pools and prohibitions on 
taking photos in holy areas during a pandemic, as well as rules made by the Ministry of Tourism and Creative Economy. The Health Potocol Assistance from the Ministry of Tourism and Creative Economy helps the Tirta Empul Temple to be reopened and can convince tourists to return with the established health protocol rules. Furthermore, the existence of this strategy is strongly supported by the strategic location of the Tirta Empul location, adequate access as well as a large courtyard and a beautiful arrangement that makes Tirta Empul visited by many tourists so that the interest of tourists is very high for Spiritual Self Cleansing "Melukat" in Tirta Empul. The implementation of good Health Protocols supported by the Wellness Tourism trend has made Tirta Empul revive and reopen to its current new life order. As well as good cooperation between Tirta Empul managers, namely the Local Traditional Village and the Regional Government to support the development of Wellness Tourism.

\section{REFERENCE}

Arikunto. (2013). Research Procedure: A Practical Approach. Jakarta: Rineka Cipta.

Global Wellness Institue. (2021). What is Wellness Tourism. Retrieved February 15, 2021, from Global Wellness Institue website:

https://globalwellnessinstitute.org/what-is-wellness/what-is-wellnesstourism/

Meikassandra, P., Prabawa, I. W. S. W., \& Mertha, I. W. (2020). Wellness

Tourism In Ubud. "A Qualitative Approach To Study The Aspects Of

Wellness Tourism Development. Journal of Business on Hospitality and Tourism, 6(1).

Ministry of Education and Culture. (2019). Factors Driving the Utilization of the Tirta Empul Temple Site. Retrieved February 15, 2021, from kebultur.kemdikbud.go.id website: https://kebultur.kemdikbud.go.id/bpcbbali/faktor-faktor-pendorongpemanektronik-situs-pura-tirta-empul/

Ministry of Tourism and Creative Economy. (2020). Care Covid 19. Retrieved February 15, 2021, from pedulicovid19.kemenparekraf.go.id website: https://pedulicovid19.kemenparekraf.go.id/pATIS-protokol-kkes-bali-safaridan-tirta-empul-siap-dibuka/

Nusa Bali. (2017). Bali Wins Spa Destination Award. Retrieved February 24, 2021, from Nusa Bali website: https:/www.nusabali.com/berita/20967/baliraih-pengharga-destinasi-spa

Rahyuda, I. (2014). Ritual Bathing: Melukat Purification Tradition as SPA Attractions and Tourist Destinations (I. Setiawan, Ed.). Denpasar: Pustaka Larasan.

Rangkuti, F. (2006). Swot Analysis Techniques Dissecting Business Cases. Jakarta: PT Gramedia Pustaka Utama. 
Rokom. (2021). Status Wabah Corona di Indonesia Ditetapkan sebagai Bencana Nasional. Retrieved January 19, 2021, from Sehat Negeriku Sehatlah Bangsaku website: https://sehatnegeriku.kemkes.go.id/baca/rilismedia/20200315/3633379/status-wabah-corona-indonesia-ditetapkanbencana-nasional/

Ross, K. (2001). Health Tourism: An Overview By Kim Ross (HSMAI Marketing Review). Retrieved February 12, 2021, from hospitalitynet.org website: https://www.hospitalitynet.org/news/4010521.html

Soeprato, E. D., \& Hindarwati, N. (2013). Business Strategy Analysis in Sekarguna Medika. Universitas Bina Nusantara.

Sugiyono. (2015). Metode Penelitian Kuantitatif, Kualitatif, dan Kombinasi (Mixed Methods) (8th ed.). Bandung: Alfabeta.

Sugiyono. (2020). Tourism Research Methods (1st ed.; N. Yuniati, Ed.). Bandung: Alfabeta Publisher.

Sutrisna, I. K. A. (2009). Bali Receives the Best Spa Destination Award. Retrieved from BeritaBali.com website: https://www.wisata.beritabali.com/read/2009/03/24/200903240007/baliterima-pengharga-destinasi-spa-terbaik 